\title{
Nucleosides as a carbon source in Bacillus subtilis: characterization of the drm-pupG operon
}

\author{
Raymond Schuch, ${ }^{1}$ Araik Garibian, ${ }^{2}$ Hans H. Saxild, ${ }^{3}$ \\ Patrick J. Piggot ${ }^{4}$ and Per Nygaard ${ }^{2}$
}

\begin{abstract}
Author for correspondence: Per Nygaard. Tel: +45353 22005. Fax: +4535322040. e-mail: Nygaard@mermaid.molbio.ku.dk
\end{abstract}

1 Department of Microbiology and Immunology, Uniformed Services University of the Health Sciences Bethesda, MD 20814, USA

2 Department of Biological Chemistry, Institute of Molecular Biology, University of Copenhagen, Sølvgade 83, 1307 Copenhagen K, Denmark

3 Department of Microbiology, Technical University of Denmark, 2800 Lyngby, Denmark

4 Department of Microbiology and Immunology, Temple University School of Medicine, Philadelphia, PA 19140, USA
In Bacillus subtilis, nucleosides are readily taken up from the growth medium and metabolized. The key enzymes in nucleoside catabolism are nucleoside phosphorylases, phosphopentomutase, and deoxyriboaldolase. The characterization of two closely linked loci, drm and pupG, which encode phosphopentomutase (Drm) and guanosine (inosine) phosphorylase (PupG), respectively, is reported here. When expressed in Escherichia coli mutant backgrounds, drm and pupG confer phosphopentomutase and purinenucleoside phosphorylase activity. Northern blot and enzyme analyses showed that drm and pupG form a dicistronic operon. Both enzymes are induced when nucleosides are present in the growth medium. Using mutants deficient in nucleoside catabolism, it was demonstrated that the low-molecular-mass effectors of this induction most likely were deoxyribose 5-phosphate and ribose 5-phosphate. Both Drm and PupG activity levels were higher when succinate rather than glucose served as the carbon source, indicating that the expression of the operon is subject to catabolite repression. Primer extension analysis identified two transcription initiation signals upstream of drm; both were utilized in induced and non-induced cells. The nucleoside-catabolizing system in B. subtilis serves to utilize the base for nucleotide synthesis while the pentose moiety serves as the carbon source. When added alone, inosine barely supports growth of $B$. subtilis. This slow nucleoside catabolism contrasts with that of $E$. coli, which grows rapidly on a nucleoside as a carbon source. When inosine was added with succinate or deoxyribose, however, a significant increase in growth was observed in $B$. subtilis. The findings of this study therefore indicate that the $B$. subtilis system for nucleoside catabolism differs greatly from the well-studied system in E. coli.

Keywords: purine-nucleoside phosphorylase, phosphopentomutase, ribonucleoside, deoxyribonucleoside, catabolism

\section{INTRODUCTION}

Nucleoside phosphorylases are involved in the intracellular metabolism of nucleosides obtained from the external environment or arising from the intracellular breakdown of nucleotides. However, the regulation and the components of this system are not well characterized in Gram-positive bacteria. Two purine-nucleoside

The GenBank accession number for the sequence data reported in this paper is U32685. phosphorylases exist in Bacillus subtilis (Jensen, 1978): one specific for adenosine (and deoxyadenosine), PupA, and another specific for guanosine (and deoxyguanosine) and inosine (and deoxyinosine), PupG. Based on uptake studies, an adenosine-specific transport system and a transport system for guanosine and inosine have been suggested for B. subtilis (Beaman et al., 1983). The nucleoside phosphorylases catalyse the cleavage of ribonucleosides and deoxyribonucleosides to the free base plus ribose 1-phosphate or deoxyribose 1-phosphate, respectively (Fig. 1). The bases serve anabolic (reutilization in nucleotide synthesis) or catabolic (use as 


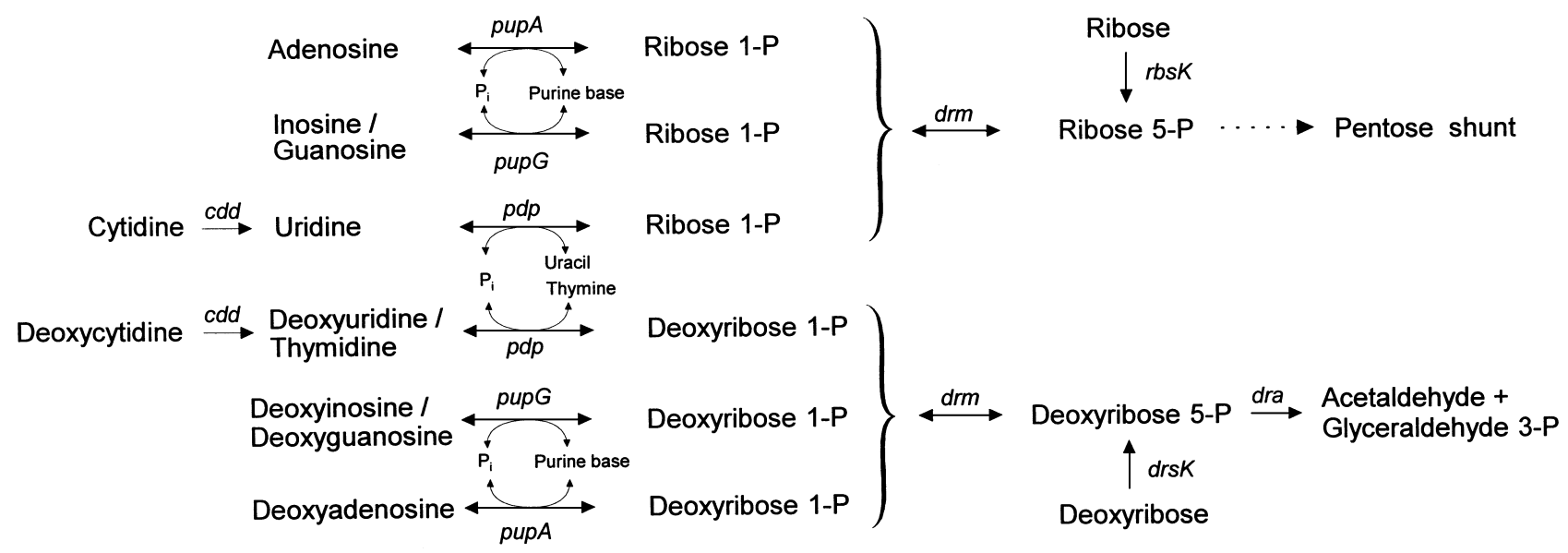

Fig. 1. Nucleoside catabolic pathways in $B$. subtilis. The enzymes are indicated by their gene symbols: cdd, cytidine deaminase; pupA, adenosine phosphorylase; pupG, guanosine (inosine) phosphorylase; pdp, pyrimidine nucleoside phosphorylase; $d r m$, phosphopentomutase, dra, deoxyriboaldolase, drsK, deoxyribokinase and rbsK, ribokinase. Purine base indicates adenine, guanine or hypoxanthine.

nitrogen sources) functions. However, the degradation of the purine bases in B. subtilis occurs only when cells are growing on poor nitrogen sources (Christiansen et al., 1997). When nucleosides are added as the sole nitrogen source, the growth rate is reduced sixfold compared with that seen when glutamate plus ammonia serve as the nitrogen source (Nygaard et al., 1996). The pathways for the degradation of nucleosides in B. subtilis are shown in Fig. 1. The ribose 1-phosphate formed from ribonucleosides can be converted to ribose 5phosphate by phosphopentomutase and then further catabolized or converted to phosphoribosylpyrophosphate which is utilized in the synthesis of nucleotides. Deoxyribose 1-phosphate, formed from deoxyribonucleosides, is also a substrate for phosphopentomutase and is converted to deoxyribose 5-phosphate. Deoxyribose 5-phosphate cannot be rescued for deoxy nucleotide synthesis and is degraded by deoxyriboaldolase encoded by the $d r a$ gene. The $d r a$ gene is located in the $d r a-n u p C-p d p$ operon. The nupC locus encodes a pyrimidine-nucleoside transporter that mediates the transport of uridine, thymidine and deoxyuridine. The $p d p$ gene encodes the only pyrimidinenucleoside phosphorylase in $B$. subtilis and can phosphorylize uridine, thymidine and deoxyuridine to the free base. Uracil can be rescued for nucleotide synthesis, but cannot serve as a nitrogen source. The $d r a-n u p C-p d p$ operon is negatively regulated by the deoR gene product (Saxild et al., 1996; Zeng \& Saxild, 1999).

In Escherichia coli and Salmonella typhimurium, a single enzyme catalyses the phosphorolytic cleavage of adenosine, guanosine, inosine and the corresponding deoxyribonucleosides (Jensen \& Nygaard, 1975). E. coli, in addition, contains a purine-nucleoside phosphorylase with specificity towards xanthosine, guanosine and inosine (Seeger et al., 1995). The synthesis of these phosphorylases and other proteins involved in nucleoside catabolism and transport in enterobacteria is induced several-fold by nucleosides added to the growth medium. As a result of this induction, the nucleosides are rapidly catabolized and serve as excellent carbon sources in E. coli (Hammer-Jespersen, 1983; MunchPetersen \& Mygind, 1983).

Previously, we cloned and sequenced two adjacent $B$. subtilis genes, encoding products similar to phosphopentomutase and purine-nucleoside phosphorylase. These loci were designated $d r m$ and $p n p$ (now referred to as $p u p G)$, and their sequences were submitted to GenBank in 1995 (accession number U32685). Here, we report the characterization of the products of these loci with respect to the regulation of their expression and their functions. These studies identify distinct differences between the $B$. subtilis nucleosidecatabolizing pathway and that of E. coli.

\section{METHODS}

Bacterial strains. The bacterial strains and plasmids used are described in Table 1. Strains constructed by transformations with plasmids as donors were confirmed by Southern-blot analysis (Sambrook et al., 1989). Strains SL6250 and SL6550 contain single-copy chromosomal insertions of plasmid pPP400 and pPP424, in the pupG and $d r m$ gene, respectively. Strain SL6479 bears a single copy $d r m-l a c Z$ transcriptional fusion inserted by double crossover recombination at the amyE locus (Table 1).

Growth and media. Cells were grown at $37{ }^{\circ} \mathrm{C}$ as described previously (Jochimsen et al., 1975; Saxild et al., 1995; Schuch \& Piggot, 1994). As minimal medium for B. subtilis the Spizizen salt-buffered medium was used; L-broth was used as rich medium. All plasmids were maintained in E. coli $\mathrm{DH} 5 \alpha$. When appropriate, bacteria were grown in the presence of antibiotics at the following concentrations: chloramphenicol, 
Table 1. Bacterial strains and plasmids

Tf., transformed; Er, erythromycin; Cm, chloramphenicol; Ap, ampicillin.

\begin{tabular}{|c|c|c|}
\hline Strain/plasmid & Characteristics & $\begin{array}{l}\text { Source/reference/ } \\
\text { construction }\end{array}$ \\
\hline \multicolumn{3}{|c|}{ B. subtilis strains } \\
\hline 168 & $\operatorname{trp} C 2$ & C. Anagnostopoulos* \\
\hline $\mathrm{HH} 232$ & $\operatorname{trp} C 2$ deoR::erm, $\mathrm{Er}^{\mathrm{R}}$ & Saxild et al. (1996) \\
\hline $\mathrm{HH} 234$ & $\operatorname{trp} C 2$ dra: : erm, $\mathrm{Er}^{\mathrm{R}}$ & Saxild et al. (1996) \\
\hline $\mathrm{HH} 244$ & metB10 lys-3 trpC2 drm::cat::erm, $\mathrm{Er}^{\mathrm{R}} \mathrm{Cm}^{\mathrm{s}}$ & $\begin{array}{l}\text { SL6550 Tf. with BamHI- } \\
\text { digested pPH46, Er }\end{array}$ \\
\hline $\mathrm{HH} 245$ & metB10 lys-3 trpC2 amyE::drm-lacZ drm::cat::erm, $\mathrm{Er}^{\mathrm{R}} \mathrm{Cm}^{\mathrm{R}}$ & HH244 Tf. with SL6479, $\mathrm{Cm}^{\mathrm{R}}$ \\
\hline MB24 & $\operatorname{trp} \mathrm{C} 2$ met $\mathrm{C} 3$ & Schuch \& Piggot (1994) \\
\hline SL4 & $\operatorname{trp} C 2$ lys-3 metB10 & Schuch \& Piggot (1994) \\
\hline SL5651 & SL4 amyE::erm, $\mathrm{Er}^{\mathrm{R}}$ & Zhang et al. (1996) \\
\hline SL6250 & $\mathrm{SL} 4 / \mathrm{pPP} 400\left(\right.$ pupG::cat), $\mathrm{Cm}^{\mathrm{R}}$ & This work \\
\hline SL6479 & SL5651/pPP420 (amyE::drm-lacZ) & This work \\
\hline SL6550 & $\mathrm{SL} 4 / \mathrm{pPP} 424(d r m:: c a t), \mathrm{Cm}^{\mathrm{R}}$ & This work \\
\hline \multicolumn{3}{|l|}{ E. coli strains } \\
\hline $\mathrm{DH} 5 \alpha$ & 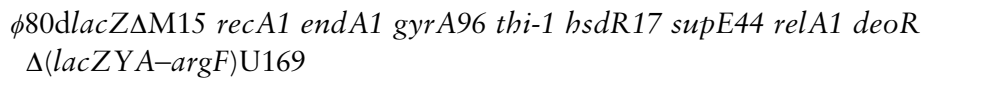 & GibcoBRL \\
\hline SØ199 & metB rpsL relA spoT supF lamB purE & Jochimsen et al. (1975) \\
\hline SØ446 & metB rpsL relA spoT supF lamB purE deoD apt & Jochimsen et al. (1975) \\
\hline HO1077 & metB rpsL relA spoT supF lamB guaA deoD deoB thyA zjj-202:: Tn10 & B. Hove-Jensen $†$ \\
\hline \multicolumn{3}{|l|}{ Plasmids } \\
\hline pBOE335 & $\mathrm{Ap}^{\mathrm{R}} \mathrm{Cm}^{\mathrm{R}}$ & Saxild et al. (1996) \\
\hline pDH32 & $\begin{array}{l}\mathrm{Cm}^{\mathrm{R}} \text { transcriptional lacZ fusion vector designed to integrate at the amyE } \\
\text { locus }\end{array}$ & Shimotsu \& Henner (1986) \\
\hline pHM2 & $\begin{array}{l}\text { Vector bearing a } 3.3 \mathrm{~kb} \text { insert of } B \text {. subtilis DNA extending from } d r m \text { to } \\
\text { spoIIA }\end{array}$ & Liu et al. (1982) \\
\hline pJH101 & $\mathrm{Cm}^{\mathrm{R}}$ integrative vector & Ferrari et al. (1983) \\
\hline pKE5 & $\begin{array}{l}\text { Vector bearing a } 3.5 \mathrm{~kb} \text { insert of } B \text {. subtilis DNA extending from } p u p G \text { to } \\
\text { spoIIM }\end{array}$ & Smith et al. (1993) \\
\hline pPH46 & $\begin{array}{l}\mathrm{Ap}^{\mathrm{R}} \mathrm{Er}^{\mathrm{R}}, \mathrm{pBOE} 335 \text { digested with StyI (blunt-ended with Klenow } \\
\text { polymerase) and ligated with a } 1 \mathrm{~kb} \text { erm-containing EcoRI fragment } \\
\text { (blunt-ended with Klenow polymerase) from pUC7erm }\end{array}$ & P. Hubrecht $\neq$ \\
\hline pUC7erm & $\operatorname{Ap}^{R} \operatorname{Er}^{R}$ & W. de Vos $\$$ \\
\hline pPP400 & $\begin{array}{l}\text { pJH101 digested with EcoRI, treated with calf intestinal phosphatase and } \\
\text { ligated with a } 364 \text { bp EcoRI internal fragment of pupG (nt } \\
2445764-2446128)\end{array}$ & This work \\
\hline pPP420 & $\begin{array}{l}\text { pDH32 digested with EcoRI (blunt-ended with Klenow polymerase) and } \\
\text { Bam HI, and ligated with a } 1 \cdot 6 \mathrm{~kb} \text { PvuII-BglII fragment containing the } \\
\text { ripX-drm intergenic region and the } 5^{\prime} \text { end of } d r m \text { (nt } 2448926-2447300 \text { ) }\end{array}$ & This work \\
\hline pPP424 & $\begin{array}{l}\text { pJH101 digested with EcoRV and BamHI, treated with calf intestinal } \\
\text { phosphatase and ligated with the } 180 \text { bp EcoRV-BglII fragment of } d r m \\
\text { (nt } 2447480-2447300 \text { ) }\end{array}$ & This work \\
\hline
\end{tabular}

*INRA, Jouy en Josas, France.

†University of Copenhagen.

$\ddagger$ Technical University of Lyngby.

SThe Netherlands Institute of Dairy Research.

$5 \mu \mathrm{g} \mathrm{ml} l^{-1}$; erythromycin, $1 \mu \mathrm{g} \mathrm{ml} \mathrm{m}^{-1}$; ampicillin, $50 \mu \mathrm{g} \mathrm{ml} \mathrm{m}^{-1}$. Spore germination was assessed by the method of Nicholson \& Setlow (1990).

Sporulation. Sporulation was induced as described by Piggot $\&$ Curtis (1987). Time is indicated in hours after the end of exponential growth. At $t_{20}-t_{24}$, the extent of heat-resistantspore formation was determined by plating appropriate diluted aliquots of the cultures on L-broth; the remainder was heated at $90{ }^{\circ} \mathrm{C}$ for $20 \mathrm{~min}$, and aliquots were plated on Lbroth. Colonies arising from heat-treated and non-heat- 
treated samples were enumerated to determine the proportion of the starting population of cells that were heat-resistant spores.

Enzyme assays. $\beta$-Galactosidase was assayed at $30^{\circ} \mathrm{C}$ as described by Nicholson \& Setlow (1990). Activities of nucleoside-catabolizing enzymes were determined at $37^{\circ} \mathrm{C}$ as described previously (Hammer-Jespersen et al., 1971; Jensen, 1978). Enzyme activity is given as nmol product formed $\mathrm{min}^{-1}$ (=1 unit).

DNA preparation and sequencing. Methods used for transformation and for chromosomal and plasmid DNA isolation have been described previously (Wu et al., 1989; Saxild et al., 1995). DNA sequencing was using a Sequenase kit (US Biochemical). All sequencing analysis was done on doublestranded plasmid DNA templates. Using plasmids pHM2 and pKE5, we determined the nucleotide sequence of the $d r m-$ pup $G$ operon.

RNA analysis. RNA preparation, Northern-blot analysis and primer extensions were performed as described previously (Penn et al., 1984; Wu et al., 1989; Nygaard et al., 1996). For Northern analyses, RNA samples (20 $\mu$ g per sample) and size markers (Promega) were separated on $1.2 \%$ agarose gels, transferred to nylon membranes (Stratagene) and probed as described by Sambrook et al. (1989). The $p u p G$-specific probe was the 364 bp EcoRI fragment (nt 2445764-2446128), and the $d r m-p u p G$-specific probe was the 823 bp HindIII fragment (nt 2445693-2446516) (Kunst et al., 1997).

\section{RESULTS}

\section{Organization and sequence of the drm-pupG gene cluster}

Sequence analysis of the region immediately upstream of the $d a c F-s p o I I A$ operon was performed using plasmids pHM2 and pKE5 (Table 1). The ORF immediately upstream of $d a c F$ encoded a putative product of 271 amino acids with extensive similarity to guanosine (inosine) nucleoside phosphorylases of a broad range of organisms. On this basis, we refer to the ORF as pupG (formerly called $p n p$ ). The second ORF was identified immediately upstream of the $p u p G$ RBS, and found to encode a putative protein of 396 residues. A BLAST search (Altschul et al., 1990) revealed that this product was $47 \%$ identical over its entire sequence to phosphopentomutase (phosphodeoxyribomutase) of E. coli (Hammer-Jespersen, 1983; Valentin-Hansen et al., 1984). We refer to this ORF herein as $d r m$. Upstream of the $d r m$ RBS was a $161 \mathrm{bp}$ intergenic region, followed by the 3' end of another ORF, now called ripX (Kunst et al., 1997). In the ripX-drm intergenic region we identified a putative rho-independent transcription terminator. The energy of binding for this stem-loop structure was calculated to be $-19 \cdot 8 \mathrm{kcal} \mathrm{mol}^{-1}\left(-82 \cdot 8 \mathrm{~kJ} \mathrm{~mol}^{-1}\right)$ using the rules of Tinoco et al. (1973). These sequences may serve to stop transcription from ripX into $\mathrm{drm}$. The remaining region between the stem-loop and $\mathrm{drm}$ (roughly $130 \mathrm{bp}$ ) could serve as a promoter region directing the transcription of $d r m$ and possibly pupG. That $d r m$ and $p u p G$ may form an operon is supported by the proximity of the $d r m$ and $p u p G$ translation stop and start codons, respectively. (a)

$\begin{array}{lll}1 & 2 & 3\end{array}$

$2 \cdot 1 \mathrm{~kb}$

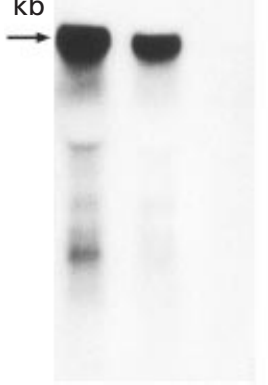

(b) 123

Fig. 2. Northern-blot analysis of the $d r m-p u p G$ region of the $B$. subtilis chromosome. RNA samples were obtained from L-broth cultures at $t_{-1}$ (lane 1$), t_{0}$ (lane 2) and $t_{2}$ (lane 3 ). The numbers are hours relative to the end of exponential growth $\left(t_{0}\right)$. The arrow indicates the major message. Probes used were either specific to pupG (a) or to both drm and pupG (b).

\section{Complementation of $E$. coli purine-nucleoside catabolism defects}

To confirm the identity of $d r m$ and $p u p G$, plasmids pKE5 (expressing $d r m$ from its native promoter) and pHM2 (expressing pupG from a vector-encoded promoter) were transformed into E. coli strains HO1077 $($ deoB) and SØ446 (purE deoD), respectively, and scored for complementation. Strain HO1077 is a phosphopentomutase-deficient mutant and cannot use thymidine as its sole carbon source (Hammer-Jespersen, 1983). Introduction of pKE5 into HO1077 restored the ability of this strain to grow on minimal medium containing inosine as a carbon source. Additionally, phosphopentomutase activity increased from $<1$ unit $(\mathrm{mg} \text { protein })^{-1}$ in HO1077 to 8 units (mg protein $)^{-1}$ in HO1077/pKE5. Strain SØ446 is purine auxotrophic and is unable to use thymidine as its sole purine source. The transformed strain SØ446/pHM2 did grow with inosine as the sole purine source, indicating that the $B$. subtilis pup $G$ gene could complement the salvage-pathway defect arising from mutation of the E. coli deoD gene. Inosine phosphorylase activity increased from $<1$ unit $(\mathrm{mg}$ protein) $)^{-1}$ in SØ446 to 85 units (mg protein) $)^{-1}$ in Sø446/pHM2. The B. subtilis drm and pupG loci, therefore, do encode phosphopentomutase and purinenucleoside phosphorylase activity, respectively.

\section{Transcription of the drm-pupG locus}

Transcription of $d r m$ and $p u p G$ during both lateexponential and early-stationary-phase L-broth cultures of strain SL4 was examined by Northern-blot analysis. Using a pupG-specific probe, we detected a predominant $2 \cdot 1 \mathrm{~kb}$ transcript (Fig. $2 \mathrm{a}$, lanes 1 and 2). With a probe containing both $\mathrm{drm}$ and $p u p G$ sequences, a similar $2 \cdot 1 \mathrm{~kb}$ message was visualized (Fig. 2b, lanes 1 and 2). 
Table 2. Effects of mutations in genes encoding enzymes involved in the catabolism of nucleosides on the expression of the pupG gene, the $d r m$ gene and the transcriptional LacZ fusion (drm-lacZ) in B. subtilis

Cells were grown in glucose and succinate minimal medium and were harvested in the exponential growth phase. Enzymes were assayed as described in the Methods section. Data are means of three or more experiments that differed by less than $15 \%$. Nucleosides were added at a concentration of $1 \mathrm{mg} \mathrm{ml}^{-1}$.

\begin{tabular}{|c|c|c|c|c|c|}
\hline Strain & $\begin{array}{l}\text { Relevant } \\
\text { genotype }\end{array}$ & $\begin{array}{l}\text { Addition to } \\
\text { medium }\end{array}$ & PupG* & Drm* & Drm-LacZ* \\
\hline \multicolumn{6}{|c|}{ Glucose-grown cultures } \\
\hline \multirow[t]{4}{*}{ SL6497 } & $d r m-l a c Z$ & None & 32 & 10 & 32 \\
\hline & & Thymidine & 63 & 20 & 68 \\
\hline & & Inosine & 53 & 18 & 73 \\
\hline & & Adenosine & 52 & 17 & 67 \\
\hline \multirow[t]{3}{*}{ SL6250 } & рирG & None & $<2$ & 9 & - \\
\hline & & Inosine & $<2$ & 10 & - \\
\hline & & Adenosine & $<2$ & 17 & - \\
\hline \multirow[t]{3}{*}{$\mathrm{HH} 245$} & $d r m$ & None & 9 & $<0.5$ & 38 \\
\hline & drm-lacZ & Thymidine & 8 & $<0.5$ & 32 \\
\hline & & Inosine & 8 & $<0.5$ & 32 \\
\hline \multirow[t]{2}{*}{$\mathrm{HH} 234$} & $d r a$ & None & 30 & 10 & - \\
\hline & & Thymidine & 55 & 16 & - \\
\hline \multirow[t]{3}{*}{$\mathrm{HH} 232$} & deoR & None & 68 & 13 & - \\
\hline & & Thymidine & 117 & 22 & - \\
\hline & & Inosine & 107 & 21 & - \\
\hline \multicolumn{6}{|c|}{ Succinate-grown cultures } \\
\hline \multirow[t]{3}{*}{ SL6497 } & $d r m-l a c Z$ & None & 85 & 29 & 69 \\
\hline & & Deoxyribose & 109 & - & 95 \\
\hline & & Ribose & 103 & - & 109 \\
\hline \multirow[t]{3}{*}{$\mathrm{HH} 245$} & $d r m$ & None & - & - & 81 \\
\hline & $d r m-l a c Z$ & Thymidine & - & - & 82 \\
\hline & & Inosine & - & - & 62 \\
\hline
\end{tabular}

*Units $(\text { mg protein })^{-1}$.

The transcript size observed in each case strongly suggests that $d r m$ (a $1.2 \mathrm{~kb}$ gene) and $p u p G($ a $0.8 \mathrm{~kb}$ gene) are cotranscribed as an operon. A minor $0.9 \mathrm{~kb}$ band was also noted. This band may reflect a low level of expression of a specific pupG transcript or a processing/breakdown product of the $2 \cdot 1 \mathrm{~kb}$ transcript. Expression of the $d r m-p u p G$ transcript was barely detectable in mRNA samples isolated at $t_{2}$ (Fig. 2, lanes 3 ), suggesting that it may be repressed in later stationary phase. To confirm the operon structure of $d r m-p u p G$, we also analysed expression of single-copy $d r m-p u p G$ transcriptional fusions to $l a c Z$ integrated at the chromosomal amyE locus. Fusion to lac $Z$ of several distinct DNA fragments extending from within $p u p G$ to at least $300 \mathrm{bp}$ upstream of it yielded background levels of $\beta$ galactosidase activity (data not shown), indicating that $p u p G$ is not likely to be transcribed from its own promoter. In contrast, a $1.4 \mathrm{~kb} P v u \mathrm{II}-B g l \mathrm{II}$ fragment containing the ripX-drm intergenic region and the $5^{\prime}$ end of $\mathrm{drm}$ fused to lacZ in SL6479 does support highlevel $\beta$-galactosidase activity in L-broth cultures: 135 units (mg protein) ${ }^{-1}$ at $t_{-1}, 176$ at $t_{0}$ and 141 at $t_{2}$. pupG is, therefore, probably cotranscribed with $\mathrm{drm}$ from a promoter in the ripX-drm intergenic region. The lower enzyme level observed at $t_{2}$ reflects the fact that the $d r m-p u p G$ operon is no longer transcribed at this stage of growth (Fig. 2).

\section{Role of Drm and Pupg in sporulation and spore germination}

Several observations show that the intracellular levels of a purine compound are important for the initiation of sporulation (Beaman et al., 1983) and for the germination of spores (Gardner \& Kornberg, 1967; Engelbrecht, 1972; Senesi et al., 1991). Based on these findings, we investigated the requirements for $\mathrm{drm}-$ pupG in spore formation. Strains SL6250 ( $p$ upG) and SL6550 (drm) displayed $65 \%$ and $61 \%$ sporulation, respectively, after overnight growth in liquid sporulation medium (a time at which the wild-type parental strain SL4 yielded $70 \%$ sporulation). Drm and PupG are, 
therefore, not required for efficient spore formation. Similarly, Drm and PupG are also dispensable for spore germination (data not shown).

\section{Identification of the low-molecular-mass effector of induction}

Preliminary analysis had indicated that the levels of Drm and PupG, but not that of PupA, were increased by the addition of ribonucleosides and deoxyribonucleosides to the growth medium. The level of PupA was uninducible and remained between 27 and 34 units $(\mathrm{mg}$ protein $)^{-1}$. The activities of Drm and PupG in wild-type cells grown in the presence of thymidine, inosine and adenosine are shown in Table 2. No induction was observed in the presence of any of the naturally occurring purine and pyrimidine bases (data not shown). To investigate whether a nucleoside must be degraded to induce, experiments were conducted with mutants defective in nucleoside catabolism. In a $p u p G$ mutant defective in inosine degradation, inosine no longer induced Drm synthesis, while increased Drm activity was seen when adenosine was added (Table 2). This indicates that a nucleoside must be phosphorylized to act as an inducer. To determine whether the first products of nucleoside degradation, ribose 1-phosphate or deoxyribose 1-phosphate, were the low-molecularmass effector molecules, induction experiments were performed in a drm mutant strain. This mutant is unable to convert ribose 1-phosphate and deoxyribose 1-phosphate, formed from inosine and thymidine, respectively, to ribose 5-phosphate and deoxyribose 5 -phosphate. The level of PupG and $\beta$-galactosidase activity from a $d r m-l a c Z$ transcriptional fusion was measured in the $d r m$ knock-out mutant $\mathrm{HH} 245$ grown in the presence of either inosine or thymidine. The PupG level was low due to the interruption of the $\mathrm{drm}$ gene and this level was not affected by addition of nucleosides to the growth medium. However, the $\beta$-galactosidase activity, driven by the $d r m$ promoter, was also unaffected. This indicates that ribose 1-phosphate and deoxyribose 1-phosphate must be further metabolized to affect the enzyme levels. In the dra mutant $\mathrm{HH} 234$, which can degrade deoxyribose 1-phosphate one step more to deoxyribose 5-phosphate and no further, addition of thymidine results in increased levels of Drm and PupG, indicating that the deoxyribose 5-phosphate formed may act as a low-molecular-mass effector molecule. Since no induction is observed in the $\mathrm{drm}$ mutant unable to convert ribose 1-phosphate to ribose 5 -phosphate, ribose 5-phosphate is a likely lowmolecular-mass effector molecule too. An alternative way of forming ribose 5-phosphate and deoxyribose 5phosphate is through phosphorylation of ribose and deoxyribose (Fig. 1). Induction experiments with ribose and deoxyribose were performed with cultures grown on succinate as the carbon source, because neither ribokinase (O'Reilly et al., 1994) nor deoxyribokinase (X. Zeng, personal communication) is synthesized when glucose serves as carbon source. When added to cultures growing on succinate both ribose and deoxyribose caused slightly increased enzyme levels in both wild-type and the $d r m$ mutant strain, supporting the suggestion that both ribose 5-phosphate and deoxyribose 5-phosphate are low-molecular-mass effector molecules. Addition of thymidine or inosine to a deoR mutant $(\mathrm{HH} 232)$ resulted in the same level of induction as in wild-type cells (Table 2). This indicates that the $B$. subtilis deoxynucleoside regulator protein DeoR, which negatively regulates the expression of the $d r a-n u p C-$ $p d p$ operon, does not appear to be involved in the regulation of expression of the $d r m-p u p G$ operon.

\section{Expression of the drm-pupG operon during growth in minimal medium}

The apparent difference in enzyme levels observed when nucleosides were added to glucose- and succinate-grown cells was studied in more detail. Expression of the $d r m-p u p G$ operon was followed by determining both Drm and PupG activity after addition of thymidine and inosine. We also investigated whether the expression was co-regulated with the $d r a-n u p C-p d p$ operon by measuring pyrimidine nucleoside phosphorylase (Pdp) activity. The level of all three enzymes was increased in thymidine-supplemented cultures; however, a more dramatic increase was observed when succinate served as the carbon source (Table 3). Addition of inosine only affected the level of Drm and PupG. There was no additive effect when both thymidine and inosine were added to the growth medium. The addition of nucleosides to the cultures in most situations resulted in an increased growth rate, most significantly in succinategrown cultures. From these experiments, we conclude that the expression of the $d r m-p u p G$ operon appears to be subject to catabolite repression.

\section{Identification of two drm-pupG transcription start sites}

From the Northern blot and lac $Z$ fusion studies, $d r m-p u p G$ appeared to be co-transcribed from a promoter in the ripX-drm intergenic region. The induction experiments indicated that transcription was increased when either a ribonucleoside or a deoxyribonucleoside was present in the growth medium. The transcription start points were identified by primer-extension mapping (Fig. 3). Total RNA was prepared from strain 168 grown in minimal succinate medium (Fig. 3, lanes 1 and 2) and in the same medium to which inosine (Fig. 3, lanes 3 and 4 ) or thymidine (Fig. 3, lanes 5 and 6) was added. Primers complementary to the nucleotide sequence from position 2447596-2447613 or 2447512-2447529 were used for both primer extension and to generate a sequence ladder. Only results obtained with the upstream primer 2447596-2447613 are shown. Two transcriptional-start sites are inferred from the $5^{\prime}$ end of the mRNA and are positioned at nucleotide numbers 2447716 and 2447687 (53 and $24 \mathrm{nt}$ upstream of the putative translational-start signal of $d r m$ ); they were detected with both primers. The same two trans- 
Table 3. Effects of nucleosides on growth and induction of the synthesis of phosphopentomutase (Drm), guanosine (inosine) phosphorylase (PupG) and pyrimidine nucleoside phosphorylase (Pdp) in B. subtilis (168)

Cells were grown in glucose and succinate minimal medium and were harvested in the exponential growth phase. Enzymes were assayed as described in the Methods section. Nucleosides were added at a concentration of $1 \mathrm{mg} \mathrm{ml}^{-1}$. Data are means of three experiments that differed by less than $15 \%$. Numbers in parentheses indicate induction (-fold).

\begin{tabular}{|c|c|c|c|c|}
\hline $\begin{array}{l}\text { Addition to growth } \\
\text { medium }\end{array}$ & Drm* & PupG* & Pdp* & $\begin{array}{l}\text { Doubling } \\
\text { time (min) }\end{array}$ \\
\hline \multicolumn{5}{|l|}{ Glucose-grown cultures } \\
\hline None & 12 & 85 & 33 & 46 \\
\hline Thymidine & $20(1 \cdot 7)$ & $113(1 \cdot 3)$ & $99(3 \cdot 0)$ & 48 \\
\hline Inosine & $20(1 \cdot 7)$ & $103(1 \cdot 2)$ & $28(0 \cdot 8)$ & 42 \\
\hline Thymidine + inosine & $19(1 \cdot 6)$ & $108(1 \cdot 3)$ & $78(2 \cdot 4)$ & 40 \\
\hline \multicolumn{5}{|c|}{ Succinate-grown cultures } \\
\hline None & 23 & 105 & 89 & 108 \\
\hline Thymidine & $70(3 \cdot 0)$ & $265(2 \cdot 5)$ & $1318(14 \cdot 8)$ & 83 \\
\hline Inosine & $40(1 \cdot 7)$ & $178(1 \cdot 7)$ & $86(1 \cdot 0)$ & 83 \\
\hline Thymidine + inosine & $61(2 \cdot 7)$ & $219(2 \cdot 1)$ & $928(10 \cdot 4)$ & 71 \\
\hline
\end{tabular}

*Units $(\mathrm{mg} \text { protein })^{-1}$.

(a)

C $\quad$ T
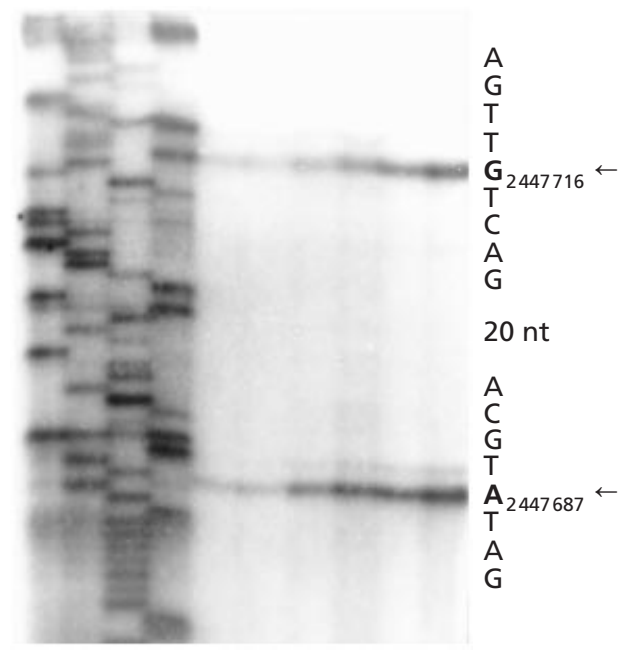

(b)

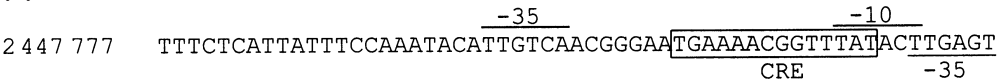

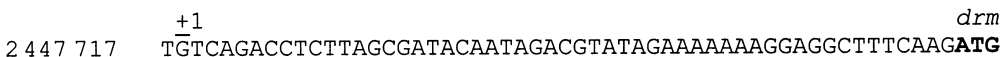

Fig. 3. Primer extension analysis of $d r m-p u p G$ mRNA from cells grown in minimal succinate medium and organization of the $d r m$-pupG regulatory region. (a) The primer used corresponds to nt 2447596-2447613. The sequence ladder (C, T, A, G) was obtained with the same primer used for CDNA synthesis. The positions that correspond to the start of transcription are marked with arrows. Lanes 1 and 2 contain RNA from cells grown in the absence of inducer. Lanes 3 and 4 contain RNA from cells grown with $1 \mathrm{mg}$ inosine $\mathrm{ml}^{-1}$ and lanes 5 and 6 contain RNA from cells grown with $1 \mathrm{mg}$ thymidine $\mathrm{ml}^{-1}$. Lanes 1, 3 and 5 contain $3 \mu \mathrm{l}$ samples and lanes 2, 4 and 6 contain $4 \mu \mathrm{l}$ samples. (b) Lines above the sequence indicate the location of the putative -35 and -10 regions of the drmP1 promoter and underlined sequences indicate the $d r m P 2$ promoter elements. The boxed sequence indicates the location of the putative cre sequence. The transcription-start points for $d r m P 1$ and $d r m P 2$ are indicated with a +1 , above or under the sequence, respectively. Letters in bold indicate the putative translational start of the $d r m$ reading frame.

criptional-start sites were seen when strain MB24 was grown in minimal glucose medium (data not shown). The distal promoter is referred to as $d r m P 1$ and the proximal as $d r m P 2$. The -10 and -35 sequences for both transcription-start sites are very similar to the $\sigma^{\mathrm{A}}$ consensus recognition sequences (TATAAT for the -10 
site and TTGACA for the -35 site). As judged by band intensity, both promoters were active under all conditions, with the highest activities in the inosine- and thymidine-supplemented cultures. The increase in transcription resulting from inosine or thymidine addition was reflected by the increased levels of Drm and PupG in these cultures (Table 3). Furthermore, the $d r m$ proximal promoter $(d r m P 2)$ appears to be favoured over the distal promoter $(d r m P 1)$ by a ratio of approximately $2: 1$.

\section{Catabolism of nucleosides}

The ability to grow on inosine $(0.1 \%)$ or thymidine $(0 \cdot 1 \%)$ as the carbon source was compared with growth on ribose $(0 \cdot 1 \%)$ and deoxyribose $(0 \cdot 1 \%)$. Except for the initial steps, the degradation of inosine and thymidine follow the same pathways as that of ribose and deoxyribose, respectively (Fig. 1). When wild-type cells were incubated in liquid media with ribose, deoxyribose, inosine or thymidine as the sole carbon source and ammonium ions as the nitrogen source, no growth on inosine or deoxyribose was observed after $36 \mathrm{~h}$, while cells grew with a doubling time of $280 \mathrm{~min}$ on ribose and $210 \mathrm{~min}$ on thymidine. The doubling time on inosine plus deoxyribose was $8 \mathrm{~h}$. For comparison, we found that E. coli (strain SØ199) grew on thymidine and inosine as the sole carbon source with a doubling time of $87 \mathrm{~min}$ and $115 \mathrm{~min}$, respectively. When $B$. subtilis strains were tested on agar plates containing inosine or deoxyribose as carbon sources and ammonium ions as nitrogen source, colonies were visible after $2 \mathrm{~d}$ incubation; they were visible after $1 \mathrm{~d}$ when thymidine served as the sole carbon source. The colonies were significantly larger than those observed when no carbon source was added to the plate. To test whether Drm or PupG activities were required for growth on nucleosides and pentoses as the carbon source, strain SL6550 (drm) and strain SL6250 ( $p$ upG) were incubated with a mixture of inosine and deoxyribose, thymidine or ribose as carbon sources. Both strains grew on ribose, and strain SL6250 also on thymidine. These results indicate that Drm activity is required for the utilization of thymidine and inosine as a carbon source and that PupG also was required for inosine utilization.

\section{DISCUSSION}

E. coli has served as a paradigm for the analysis and understanding of metabolic pathways in bacteria. However, often there are major differences with respect to how pathways from different bacteria are organized and regulated. The anabolic pathways responsible for purine-nucleoside salvage in E. coli and B. subtilis are quite different. Only E. coli is able to phosphorylate guanosine and inosine to GMP and IMP, and only $B$. subtilis can phosphorylate deoxyadenosine and deoxyguanosine, to dAMP and dGMP (Neuhard \& Nygaard, 1987; Nygaard, 1993).

The very efficient nucleoside transport and catabolism found in E. coli and the great number of genes encoding regulatory proteins, transport proteins and enzymes involved in nucleoside catabolism do not have counterparts in B. subtilis. In E. coli, the genes encoding most of the proteins involved in purine- and pyrimidinenucleoside catabolism are organized in a regulon composed of several single genes : nupC, nupG, tsx, cytX (all encoding transport proteins), $u d p$, (encoding uridine phosphorylase), $c d d$ (encoding cytidine deaminase) and the deo operon deoABCD (Valentin-Hansen et al., 1996). This regulon is negatively regulated by the DeoR and CytR proteins. A second operon, $x a p A B$ (encoding a purine-nucleoside phosphorylase and a nucleoside transport protein), is not part of the regulon, but is positively regulated by the XapR protein (Seeger et al., 1995). The E. coli deoB and deoD genes (equivalent to the B. subtilis drm and pupG genes) are encoded in the deo operon, together with deoA (encoding thymidine phosphorylase) and $\operatorname{deo}_{\mathrm{C}}$ (encoding deoxyriboaldolase). The low-molecular-mass effector that reacts with the regulatory DeoR protein of E. coli is deoxyribose 5-phosphate, while ribose 5-phosphate is not active (Hammer-Jespersen, 1983). CytR, on the other hand, reacts with cytidine. Additionally, the CytRcontrolled promoters are activated by the cAMP receptor protein (Valentin-Hansen et al., 1996). In B. subtilis, the genes identified corresponding to those of the E. coli regulon are located in two operons: the $d r m-p u p G$ operon and the $d r a-n u p C-p d p$ operon, in addition to the single genes $c d d$, encoding cytidine deaminase, and $p u p A$. Expression of $p u p A$ and $c d d$ has been found not to respond to nucleosides in the growth medium (Nygaard, 1993). The $d r a-n u p C-p d p$ operon is regulated by the DeoR protein (Saxild et al., 1996; Zeng \& Saxild, 1999) and the $d r m-p u p G$ operon is not. However, the expression of both operons is increased by deoxyribonucleosides. Additionally, only the expression of drm-pupG is affected by the presence of ribonucleosides. Our finding that the transcription of the $d r m-p u p G$ operon started at two different sites could suggest distinct ribose 5-phosphate- and deoxyribose 5phosphate-controlled start sites. This turned out not to be the case, as similar increases in transcription from both the $d r m P 1$ and $d r m P 2$ promoter were detected in the presence of either thymidine or inosine (Fig. 3). Most likely there is a protein that negatively regulates the initiation of transcription, and which recognizes both ribose 5 -phosphate and deoxyribose 5-phosphate. We observed a major difference between growth on inosine or thymidine as the carbon source, compared with growth on free ribose and deoxyribose. Significant growth was only observed when thymidine or ribose served as the sole carbon source. While the level of the nucleoside-catabolizing enzymes is comparable to that of E. coli, the nucleoside-transport activity is lower in $B$. subtilis. We therefore suggest that what limits the catabolism of nucleosides in this organism is the transport of nucleosides. In agreement with this is our finding that an E. coli strain carrying a plasmid (pHM2) with the cloned $\mathrm{drm}$ gene grew well on inosine as the carbon source although the Drm level was only $30 \%$ of that in wild-type B. subtilis, which cannot grow on inosine as the sole carbon source. 
Synthesis of the nucleoside-catabolic enzymes in $B$. subtilis is subject to catabolite repression (Saxild et al., 1996). Catabolite repression can occur via a common regulatory mechanism that involves the cis-acting cre element, 5'-TGWAANCGNTNWCA-3', which is active whether located in the promoter region or within a gene (Miwa et al., 1997). Two such putative elements were found in the drm-pupG operon. The first putative cre site (nucleotide 2447739-2447726) has 12 out of 14 matches with the common sequence, and overlaps with the putative -10 region of the $\operatorname{drmP} 1$ promoter and extends to within $2 \mathrm{nt}$ of the putative -35 region of the drmP2 promoter. The second putative cre site (nucleotide 2446168-2446155) lies in the pupG coding region and matches 11 out of 14 positions. For both cre sites the mismatches are located at the $3^{\prime}$ end. The presence of these sites offers an explanation for the observed induction pattern (Table 3): that the extent of induction of Drm and PupG in particular was lower in glucose-grown cultures than in succinate-grown cultures.

A few studies dealing with nucleoside catabolism in other bacilli have shown that the levels of phosphopentomutase and purine-nucleoside phosphorylase in Bacillus cereus and Bacillus thuringiensis are increased by nucleosides and nucleotides in the growth medium (Gardner \& Kornberg, 1967; Ipata et al., 1983; Grigorieva \& Sukhodolets, 1979). Another aspect of purine-nucleoside metabolism found in E. coli and incidentally also in B. cereus is the involvement of purine-nucleoside phosphorylases and adenosine deaminase in the interconversion of adenine compounds to guanine compounds. Such a pathway is not present in B. subtilis (Nygaard et al., 1996).

\section{ACKNOWLEDGEMENTS}

We wish to thank Jenny Steno Christensen for excellent technical assistance. This work was supported by Public Health Service grant GM43577 (P JP) and training grant 5 T32 AI07101 (R S) from the National Institutes of Health, USA and by the Danish Centre for Microbiology grants to PN and AG.

\section{REFERENCES}

Altschul, S. F., Gish, W., Miller, W., Myers, E. W. \& Lipman, D. J. (1990). Basic local alignment search tool. J Mol Biol 215, 403-410.

Beaman, T. C., Hitchins, A. D., Ochi, K., Vasantha, N., Endo, T. \& Freese, E. (1983). Specificity and control of uptake of purines and other compounds in Bacillus subtilis. J Bacteriol 156, 1107-1117.

Christiansen, L. C., Schou, S., Nygaard, P. \& Saxild, H. H. (1997). Xanthine metabolism in Bacillus subtilis: characterization of the $x p t-p b u X$ operon and evidence for purine- and nitrogencontrolled expression of genes involved in xanthine salvage and catabolism. J Bacteriol 179, 2540-2550.

Engelbrecht, H. L. (1972). Time course of purine-nucleoside phosphorylase occurrence in sporulation of Bacillus cereus. J Bacteriol 111, 33-36.

Ferrari, F. A., Nguyen, A., Lang, D. \& Hoch, J. A. (1983). Construction and properties of an integrable plasmid for Bacillus subtilis. J Bacteriol 154, 1513-1515.
Gardner, R. \& Kornberg, A. (1967). Biochemical studies of bacterial sporulation and germination. J Biol Chem 242, 2383-2388.

Grigorieva, T. M. \& Sukhodolets, V. V. (1979). Regulation of pyrimidine nucleoside phosphorylase activity in Bacillus thuringiensis var. galleriae: the induction of the enzyme activity at different growth stages of bacterial cells. Genetica 15, 1169-1176.

Hammer-Jespersen, K. (1983). Nucleoside catabolism. In Metabolism of Nucleotides, Nucleosides and Nucleobases in Microorganisms, pp. 203-258. Edited by A. Munch-Petersen. New York: Academic Press.

Hammer-Jespersen, K., Munch-Petersen, A., Nygaard, P. \& Schwartz, M. (1971). Induction of enzymes involved in the catabolism of deoxyribonucleosides and ribonucleosides in Escherichia coli K12. Eur J Biochem 19, 533-538.

Ipata, P. L., Sgarrella, F., Catalani, R. \& Tozzi, M. G. (1983). Induction of phosphoribomutase in Bacillus cereus growing on nucleosides. Biochim Biophys Acta 755, 253-256.

Jensen, K. F. (1978). Two purine-nucleoside phosphorylases in Bacillus subtilis: purification and some properties of the adenosine-specific phosphorylase. Biochim Biophys Acta 523, 346-356.

Jensen, K. F. \& Nygaard, P. (1975). Purine-nucleoside phosphorylase from Escherichia coli and Salmonella typhimurium: purification and some properties. Eur J Biochem 51, 253-265.

Jochimsen, B., Nygaard, P. \& Vestergaard, T. (1975). Location on the chromosome of Escherichia coli of genes governing purine metabolism. Mol Gen Genet 143, 85-91.

Kunst, F., Ogasawara, N., Moszer, I. \& 148 other authors (1997). The complete genome sequence of the Gram-positive bacterium Bacillus subtilis. Nature 390, 249-256.

Liu, H. M., Chak, K. F. \& Piggot, P. J. (1982). Isolation and characterization of a recombinant plasmid carrying a functional part of the Bacillus subtilis spoIIA locus. J Gen Microbiol 128, 2805-2812.

Miwa, Y., Nagura, K., Eguchi, S., Fukuda, H., Deutsher, J. \& Fujita, Y. (1997). Catabolite repression of the Bacillus subtilis gnt operon exerted by two catabolic-responsive elements. Mol Microbiol 23, 1203-1213.

Munch-Petersen, A. \& Mygind, B. (1983). Transport of nucleic acids precursors. In Metabolism of Nucleotides, Nucleosides and Nucleobases in Microorganisms, pp. 95-148. Edited by A. Munch-Petersen. New York: Academic Press.

Neuhard, J. \& Nygaard, P. (1987). Purines and pyrimidines. In Escherichia coli and Salmonella typhimurium: Cellular and Molecular Biology, vol. 1, pp. 445-473. Edited by F. C. Neidhardt and others. Washington, DC: American Society for Microbiology.

Nicholson, W. L. \& Setlow, P. (1990). Sporulation, germination and outgrowth. In Molecular Biological Methods for Bacillus, pp. 391-429. Edited by C. R. Harwood \& S. M. Cutting. Chichester: Wiley.

Nygaard, P. (1993). Purine and pyrimidine salvage pathways. In Bacillus subtilis and Other Gram-Positive Bacteria, pp. 359-378. Edited by A. L. Sonenshein, J. A. Hoch \& R. Losick. Washington, DC: American Society for Microbiology.

Nygaard, P., Duckert, P. \& Saxild, H. H. (1996). Role of adenine deaminase in purine salvage and nitrogen metabolism, and characterization of the ade gene in Bacillus subtilis. J Bacteriol 178, 846-853.

O'Reilly, M., Woodson, K., Dowds, B. C. \& Devine, K. (1994). The citrulline biosynthetic operon, $\arg C-F$, and a ribose transport 
operon, rbs, from Bacillus subtilis are negatively regulated by Spo0A. Mol Microbiol 11, 87-98.

Penn, M. D., Thireos, G. \& Greer, H. (1984). Temporal analysis of general control of amino acid biosynthesis in Saccharomyces cerevisiae: role of positive regulatory genes in initiation and maintenance of mRNA derepression. Mol Cell Biol 4, 520-528.

Piggot, P. J. \& Curtis, C. A. M. (1987). Analysis of the regulation of gene expression during Bacillus subtilis sporulation by manipulation of the copy number of spo-lacZ fusions. J Bacteriol 169, 1260-1265.

Sambrook, J., Fritsch, E. F. \& Maniatis, T. (1989). Molecular Cloning: a Laboratory Manual, 2nd edn. Cold Spring Harbor, NY: Cold Spring Harbor Laboratory.

Saxild, H. H., Jacobsen, J. H. \& Nygaard, P. (1995). Functional analysis of the Bacillus subtilis purT gene encoding formatedependent glycinamide ribonucleotide transformylase. Microbiology 141, 2211-2218.

Saxild, H. H., Andersen, L. N. \& Hammer, K. (1996). dra$n u p C-p d p$ operon of Bacillus subtilis: nucleotide sequence, induction by deoxyribonucleosides, and transcriptional regulation by the $d e o R$-encoded DeoR repressor protein. J Bacteriol 178, 424-434.

Schuch, R. \& Piggot, P. J. (1994). The dacF-spollA operon of Bacillus subtilis encoding $\sigma^{\mathrm{F}}$, is autoregulated. J Bacteriol 176, 4104-4110.

Seeger, C., Poulsen, C. \& Dandanell, G. (1995). Identification and characterization of genes $(x a p A, x a p B$, and $x a p R)$ involved in xanthosine catabolism in Escherichia coli. J Bacteriol 177, 5506-5516.

Senesi, S., Cercignani, G., Freer, G., Batoni, G., Barnini, S. \& Ota, F. (1991). Structural and stereospecific requirements for the nucleoside-triggered germination of Bacillus cereus spores. J Gen Microbiol 137, 399-404.

Shimotsu, H. \& Henner, D. J. (1986). Construction of a single-copy integration vector and its use in analysis of regulation of the $\operatorname{trp}$ operon of Bacillus subtilis. Gene 43, 85-94.

Smith, K., Bayer, M. E. \& Youngman, P. (1993). Physical and functional characterization of the Bacillus subtilis spoIIM gene. $J$ Bacteriol 175, 3607-3617.

Tinoco, I., Jr, Borer, P. N., Dengler, B. \& Levine, M. D. (1973). Improved estimation of secondary structure in ribonucleic acids. Nature 246, 40-41.

Valentin-Hansen, P., Hammer, K., Larsen, J. E. L. \& Svendsen, I. (1984). The internal regulated promoter of the deo operon of Escherichia coli K-12. Nucleic Acids Res 12, 5211-5224.

Valentin-Hansen, P., Søgaard-Andersen, L. \& Pedersen, H. (1996). A flexible partnership: the CytR anti-activator and the cAMPCRP activator protein, comrades in transcription control. $\mathrm{Mol}$ Microbiol 20, 461-466.

Wu, J.-J., Howard, M. G. \& Piggot, P. J. (1989). Regulation of transcription of the Bacillus subtilis spoIIA locus. J Bacteriol 171, 692-698.

Zeng, X. \& Saxild, H. H. (1999). Identification and characterization of a DeoR-specific operator sequence essential for induction of $d r a-n u p C-p d p$ operon expression in Bacillus subtilis. J Bacteriol 181, 1719-1727.

Zhang, L., Higgins, M. L., Piggot, P. J. \& Karow, M. (1996). Analysis of the role of prespore gene expression in the compartmentalization of mother cell-specific gene expression during sporulation in Bacillus subtilis. J Bacteriol 178, 2813-2817.

Received 22 March 1999; revised 14 May 1999; accepted 28 May 1999. 